\title{
Expression of neuritin in human lung squamous cell carcinoma
}

\author{
Mengjie Liang ${ }^{1,2 \#}$, Yin Song ${ }^{1 \#}$, Wen Zhang ${ }^{1 *}$, Feng $\mathrm{Xu}^{1}$, Pengfei $\mathrm{Ba}^{1}$, Li Yang ${ }^{1}$, Jin Huang ${ }^{1}$ \\ ${ }^{1}$ The Key Laboratory of Xinjiang Endemic \& Ethnic Diseases and Department of Biochemistry, Shihezi University School of Medicine, Shihezi \\ 832002, China; ${ }^{2}$ Department of Clinical Laboratory, Hospital of Xinjiang Production and Construction Corps/Second Affiliated Hospital, Medical \\ School of Shihezi University, Urumqi, Xinjiang 832000, China \\ Contributions: (I) Conception and design: All authors; (II) Administrative support: J Huang; (III) Provision of study materials or patients: J Huang; (IV) \\ Collection and assembly of data: P Ba, J Huang; (V) Data analysis and interpretation: M Liang, W Zhang, L Yang, J Huang; (VI) Manuscript writing: \\ All authors; (VII) Final approval of manuscript: All authors. \\ \#These authors contributed equally to this work. \\ Correspondence to: Jin Huang, MD, PhD; Li Yang, MD. The Key Laboratory of Xinjiang Endemic \& Ethnic Diseases and Department of \\ Biochemistry, Shihezi University School of Medicine, Shihezi 832002, China. Email: huangjin623@163.com; 33225965@qq.com.
}

Background: This study aimed to investigate the expression of neuritin in four common cancers, and to explore the association between neuritin expression and the occurrence and development of cancer.

Methods: We initially examined neuritin expression in human cervical, endometrial, oesophageal, and lung cancer tissues by immunohistochemistry (IHC). Based on these results, we further examined its expression in lung squamous cell carcinoma (LUSC) tissues by IHC and reverse transcription-polymerase chain reaction (RT-PCR).

Results: Neuritin expression levels were higher in all cancer tissues compared with normal control tissues. Neuritin protein and gene expression levels were significantly higher in LUSC tissues compared with normal lung tissues $(\mathrm{P}<0.001)$, according to IHC and RT-PCR, respectively. Neuritin expression levels decreased significantly with increased clinical TNM stage $(\mathrm{I}-\mathrm{IV})$ and distant metastasis $(\mathrm{P}<0.05)$.

Conclusion: Neuritin may have clinical value as a novel diagnostic and prognostic marker in patients with LUSC.

Keywords: Cancer; diagnosis; lung squamous cell carcinoma (LUSC); neuritin; prognosis

Submitted Mar 08, 2019. Accepted for publication Sep 04, 2019.

doi: $10.21037 /$ tcr.2019.09.52

View this article at: http://dx.doi.org/10.21037/tcr.2019.09.52

\section{Introduction}

Neuritin, also known as candidate plasticity-related gene 15, is a novel neurotrophin discovered by Nedivi et al. (1). It is an activity-induced glycosylphosphatidylinositol-anchored axonal protein, mainly expressed in the brain $(2,3)$. Neuritin has been proven to have a profound effect in the nervous system by promoting neurite outgrowth and dendritic growth, regulating synaptic plasticity, promoting synaptic maturation and neuronal migration, regenerating peripheral nerves and spinal axons, and regulating proliferative neuron apoptosis (3-13). However, information on the functions of neuritin in other organs is scarce.

Numerous studies have revealed that neuritin is also expressed in the liver, lungs, and skeletal muscle $(4,14,15)$, suggesting a possible role in non-nervous system organs. Furthermore, neuritin overexpression has been reported in some tumour cells and in relation to the promotion of tumour angiogenesis (16). Neuritin was also highly upregulated in hypoxic cells (17-19) and was shown to inhibit cell apoptosis $(7,11,20)$. Overall, these studies suggested that neuritin may not function exclusively as a neurotrophin in the nervous system, and may also play crucial roles in tumourigenesis.

Cervical cancer, endometrial cancer, oesophageal cancer, and lung squamous cell carcinoma (LUSC) are the most common cancers affecting people worldwide (21-24). More effective methods of detecting early stage cancers 
are urgently required to improve their diagnosis and treatment. In this study, we initially investigated neuritin immunoreactivity in lung, cervical, endometrial, and oesophageal cancers. Based on these results, we further examined neuritin protein and gene expression in LUSC tissues by immunohistochemistry (IHC) and reverse transcription-polymerase chain reaction (RT-PCR), and evaluated the relationships between neuritin expression and clinical features in patients with LUSC.

\section{Methods}

\section{Patients and tissue specimens}

We obtained tissues from 30 patients with LUSC, five patients with cervical cancer, five with endometrial cancer, and five with oesophageal cancer for investigation of neuritin expression. All patients had histologically confirmed cancer with no history of any other cancers, and all patients underwent resection at the First Affiliated Hospital of Shihezi University School of Medicine (Shehezi, Xinjiang, China). None of the patients had received any preoperative anticancer treatment. Data on clinicopathological parameters, including sex, age, tumour stage, lymph node metastasis, and histological grade were obtained from hospital and surgical records. The present study was approved by the Human Ethics Committee of the First Affiliated Hospital of Shihezi University School of Medicine (No. 2007-025-01), and written informed consent was obtained from all patients according to the committee's regulations.

\section{IHC}

IHC was conducted using paraffin-embedded tumour tissues, and matched normal tissues obtained from the autopsy files of the Department of Pathology, the First Affiliated Hospital of Shihezi University School of Medicine. IHC staining was performed using a ChemMate $^{\mathrm{TM}}$ Dako EnVision ${ }^{\mathrm{TM}}$ Detection Kit (GK500705, Dako, Glostrup, Denmark) according to the manufacturer's instructions. The specimens were cut into $4-\mu \mathrm{m}$ sections, unfolded on the surface of water at $25^{\circ} \mathrm{C}$, and then laid on polysine adhesion slides overnight at $60{ }^{\circ} \mathrm{C}$. The slides were deparaffinized with dimethylbenzene and rehydrated through a graded series of ethanols $(100 \%, 95 \%, 90 \%$, $80 \%$, and $70 \%)$. After washing three times with phosphatebuffered saline (PBS), the slides were boiled in antigen retrieval buffer $(0.01 \mathrm{M}$ sodium citrate-hydrochloric acid, $\mathrm{pH}$ 6.0) for $10-15 \mathrm{~min}$ in a microwave oven at $95-97{ }^{\circ} \mathrm{C}$. Endogenous peroxidase was blocked by incubation with $3 \%$ peroxide for $10 \mathrm{~min}$ followed by three additional rinses in PBS for $5 \mathrm{~min}$ each. Nonspecific binding was blocked by incubation with bovine serum albumin. The sections were then incubated with primary polyclonal rabbit anti-neuritin (FL-142) antibody (sc-25651, 1:50, Santa Cruz Biotechnology, Santa Cruz, CA, USA) at $4{ }^{\circ} \mathrm{C}$ overnight, followed by PBS, and subsequently incubated with ChemMate ${ }^{\mathrm{TM}}$ EnVision ${ }^{\mathrm{TM}} / \mathrm{HRP}$ (Dako) at room temperature for $30 \mathrm{~min}$. After further washing in PBS, the sections were developed using 3,3'-diaminobenzidine, washed under running tap water, lightly counterstained with haematoxylin, dehydrated, and mounted with coverslips. Negative control experiments were conducted by replacing the primary antibody with PBS, and cerebellum tissue was used as a positive control. All the slides were reviewed by experienced pathologists. Neuritin immunostaining was scored by multiplying the intensity score $(0=$ negative, $1=$ weak, $2=$ moderate, and $3=$ strong) by the percentage of positively stained cells $(0=0 \% ; 1=1-33.3 \% ; 2=33-66.6 \%$; and $3=66.6-100 \%)$. Neuritin expression was considered positive when the IHC score was $\geq 2$.

\section{$R N A$ extraction and RT-PCR}

RNA was isolated from fresh tissue samples obtained from patients in the First Affiliated Hospital of Shihezi University School of Medicine within 30 min after resection, and immediately stored in liquid nitrogen until use. Total RNA was extracted using TRIzol reagent (Invitrogen, Carlsbad, CA, USA) according to the manufacturer's instructions. RNA integrity was verified by $1.5 \%$ agarose gel electrophoresis and the quality and concentration of the RNA at 260 and $280 \mathrm{~nm}$ were determined using a UV spectrophotometer. The concentration was validated using the formula RNA $(\mu \mathrm{g} / \mathrm{mL})=\mathrm{OD}_{260} \times 40 \mu \mathrm{g} / \mathrm{mL} \times$ dilution ratio. Total RNA $(1 \mu \mathrm{g})$ was reverse-transcribed in a $25-\mu \mathrm{L}$ reaction volume (containing $12 \mu \mathrm{L}$ RNase-free $\mathrm{dH}_{2} \mathrm{O}$, $5 \mu \mathrm{L}$ One Step RNA PCR Buffer, $5 \mathrm{mM} \mathrm{MgCl}_{2}, 1 \mathrm{mM}$ dNTP mixture, $0.4 \mu M$ P1, $0.4 \mu M$ P2, $0.8 \mathrm{U} / \mu \mathrm{L}$ RNase inhibitor, $0.1 \mathrm{U} / \mu \mathrm{L}$ AMV RTase XL, and $0.1 \mathrm{U} / \mu \mathrm{L}$ AMVOptimized Taq) using a One Step RNA PCR Kit (AMV) (RRO24A, TaKaRa, Ohtsu, Shiga, Japan) according to the manufacturer's instructions. The reverse transcription reactions were performed in one cycle of $50^{\circ} \mathrm{C}$ for $30 \mathrm{~min}$ and $94{ }^{\circ} \mathrm{C}$ for $120 \mathrm{~s}$, followed by PCR for 30 cycles of $94{ }^{\circ} \mathrm{C}$ 

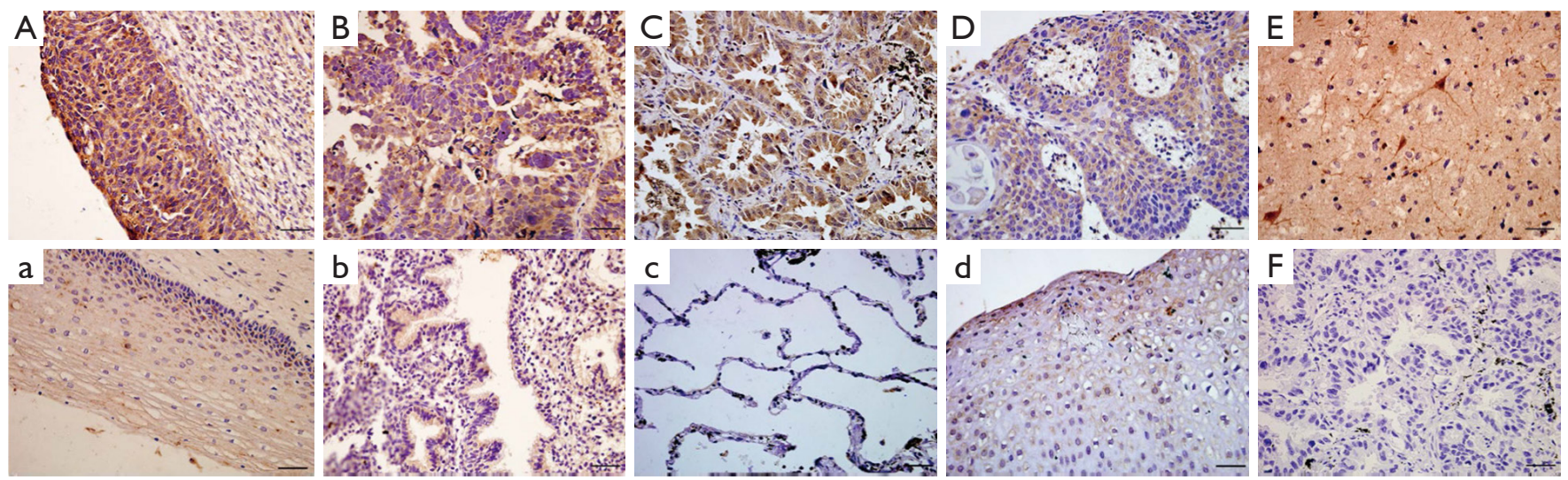

Figure 1 Immunohistochemical evaluation of neuritin expression profiles in different human cancer tissues and corresponding normal tissues. Representative IHC images stained using anti-neuritin antibody (1:50 dilution) in human cancers and corresponding normal specimens. Scale bar, $100 \mu \mathrm{m}$. (A) Cervical cancer; (B) endometrial cancer; (C) LUSC; (D) oesophageal cancer tissues; (E) positive control: cerebellum; (F) negative control. a-d: Corresponding normal human tissues for A-D.

for $30 \mathrm{~s}, 64{ }^{\circ} \mathrm{C}$ for $30 \mathrm{~s}$, and $72{ }^{\circ} \mathrm{C}$ for $90 \mathrm{~s}$. Neuritin gene amplification was carried out using the reverse primer $\mathrm{P} 1$ (5'-CCGGAATTCCAATGGGACTTAAGTTGAACG GCAG ATAT-3') and forward primer P2 (5'-CGCGG ATCCGAAGGAAAGCCAGGTCGCTAAAGCT-3'). Neuritin expression levels were normalized to values for the endogenous reference gene glyceraldehyde-3-phosphate dehydrogenase (GAPDH).

\section{Statistical analysis}

Statistical analysis was performed using the SPSS statistical software package (SPSS version 17.0; SPSS, Chicago, IL, USA). Differences between groups were analysed using Fisher's exact test and the $\chi^{2}$ test. A P value of $<0.05$ was regarded as statistically significant.

\section{Results}

\section{Neuritin protein expression profiles in tumour tissues and corresponding normal tissues}

Neuritin protein expression was detected in human cervical cancer, endometrial cancer, oesophageal cancer, and LUSC tissues and in their corresponding normal tissues (Figure 1). Five samples were obtained from each specimen. Immunoreactivity for neuritin was located in the cytoplasm. Cervical cancer, endometrial cancer, and LUSC tissue specimens showed moderate or strong immunostaining for neuritin, whereas oesophageal cancer tissues showed relatively weaker expression. Neuritin staining was weakly positive in normal cervical, endometrial, and oesophageal tissues but negative in normal lung tissue. Neuritin expression thus clearly differed between normal lung tissue and LUSC tissue.

\section{Patient characteristics}

Specimens from 30 patients with LUSC were subjected to IHC analysis of neuritin expression. The relationships between neuritin protein expression and clinicopathologic parameters are shown in Table 1. The database on which these analyses were based was created by the International Association for the Study of Lung Cancer, to inform revisions to lung cancer guidelines in the seventh edition of the Union for International Cancer Control TNM Classification of Malignant Tumor staging manual. The 30 patients included 21 men, and the male-to-female ratio was 7:3. The median age was 56 years (range, $37-72$ years) and 14 patients (46.7\%) were $>60$ years old. Eighteen patients $(60.0 \%)$ had advanced clinical TNM stage (stage III-IV) disease.

\section{Association between neuritin protein expression and clinical TNM stage in buman LUSC}

Neuritin protein expression was determined by IHC in 30 human LUSC tissues and 20 normal lung tissue samples. Representative images are shown in Figure 2. Among the 30 squamous cell carcinoma tissue specimens, five $(16.7 \%)$ were scored as 0 to $1+, 14(46.7 \%)$ as $2+$ to $4+$, 
Table 1 Patient characteristics

\begin{tabular}{|c|c|c|c|c|}
\hline \multirow{2}{*}{ Characteristic } & \multirow{2}{*}{$\begin{array}{l}\text { Total } \\
(\mathrm{n}=30)\end{array}$} & \multicolumn{2}{|c|}{ Neuritin expression } & \multirow{2}{*}{$P$ value } \\
\hline & & Positive & Negative & \\
\hline Sex & & & & 0.622 \\
\hline Male & 21 & 18 & 3 & \\
\hline Female & 9 & 7 & 2 & \\
\hline Age, years & & & & 0.642 \\
\hline$\leq 60$ & 16 & 14 & 2 & \\
\hline$>60$ & 14 & 11 & 3 & \\
\hline T stage & & & & 1.000 \\
\hline $\mathrm{T}_{1}-\mathrm{T}_{2}$ & 16 & 13 & 3 & \\
\hline $\mathrm{T}_{3}-\mathrm{T}_{4}$ & 14 & 12 & 2 & \\
\hline $\mathrm{N}$ & & & & 0.304 \\
\hline $\mathrm{N}_{0}-\mathrm{N}_{1}$ & 23 & 18 & 5 & \\
\hline $\mathrm{N}_{3}-\mathrm{N}_{4}$ & 7 & 7 & 0 & \\
\hline$M$ & & & & $0.023^{*}$ \\
\hline$M_{0}$ & 28 & 25 & 3 & \\
\hline$M_{1}$ & 2 & 0 & 2 & \\
\hline TNM stages & & & & $0.049^{\star}$ \\
\hline I & 3 & 3 & 0 & \\
\hline II & 9 & 8 & 1 & \\
\hline III & 16 & 14 & 2 & \\
\hline IV & 2 & 0 & 2 & \\
\hline Histological grade & & & & 1.000 \\
\hline Well-differentiated & 10 & 8 & 2 & \\
\hline $\begin{array}{l}\text { Moderately- } \\
\text { differentiated }\end{array}$ & 14 & 12 & 2 & \\
\hline Poorly-differentiated & 6 & 5 & 1 & \\
\hline
\end{tabular}

${ }^{*} \mathrm{P}<0.05$; $\mathrm{T}$, primary tumour; $\mathrm{N}$, regional lymph nodes; $\mathrm{M}$, distant metastases.

and $11(36.7 \%)$ as $6+$ to $9+$. Among the 20 normal lung tissue specimens, 15 (75.0\%) were scored as 0 to $1+$ and only five $(25.0 \%)$ were scored as $2+$. Accordingly, 25 of the 30 squamous cell carcinoma tissue specimens (83.3\%) were positive for neuritin expression compared with five of the 20 normal lung tissue specimens (25.0\%), with all the other specimens testing negative for neuritin expression (Figure 2). The neuritin-positivity ratio was significantly higher among squamous cell carcinoma tissues compared with normal lung tissues $(\mathrm{P}<0.001)$. The positivity ratio was also significantly lower in patients with higher clinical TNM stage (I-IV, $\mathrm{P}=0.049$ ), and in patients with distant metastasis of LUSC compared with those without $(\mathrm{P}=0.023)$. However, there was no association between neuritin positivity and patient age, sex, local lymph node metastasis, or histological grade (Table 1).

\section{Neuritin gene expression in buman LUSC and normal lung tissues by RT-PCR}

We confirmed the difference in neuritin expression between LUSC tissues and normal lung tissues by RT-PCR. A DNA fragment of the expected size for neuritin (446 bp) was amplified by agarose gel electrophoresis of DNA from LUSC specimens, but not from normal lung tissue specimens (Figure 3).

\section{Discussion}

Neuritin is a neurotrophic factor with multiple roles in neural development and plasticity $(9,12,25-28)$. However, some recent reports have also shown an association between neuritin and cancers, including upregulation of neuritin in Kaposi's sarcoma, astrocytoma, and glioma cell lines, and in gastric cancer tissues and melanoma patients $(20,29-31)$. These findings suggest that neuritin may be related to tumour development.

We initially examined the previously unreported expression of neuritin in common human cancers, including cervical, endometrial, and oesophageal cancer, and in LUSC. Expression levels of neuritin were higher in carcinoma tissues than in the corresponding normal tissues, with a particularly marked difference in between LUSC and normal lung tissues. We therefore detected neuritin protein and mRNA expression in 30 LUSC tissues and 20 normal lung tissues, and showed that the neuritin-positivity ratio was significantly higher in squamous cell carcinoma tissues $(83.3 \%)$ than in normal lung tissues $(25 \%)$, according to both IHC and RT-PCR. We therefore speculate that neuritin may participate in the development of LUSC.

We also investigated the clinical value of neuritin in LUSC by analysing its expression in relation to various clinical features in patients with LUSC. Neuritin positivity was significantly lower in patients with higher grade tumours, and in patients with distant metastasis, suggesting that high expression levels of neuritin may be negatively correlated with the degree of malignant differentiation and 

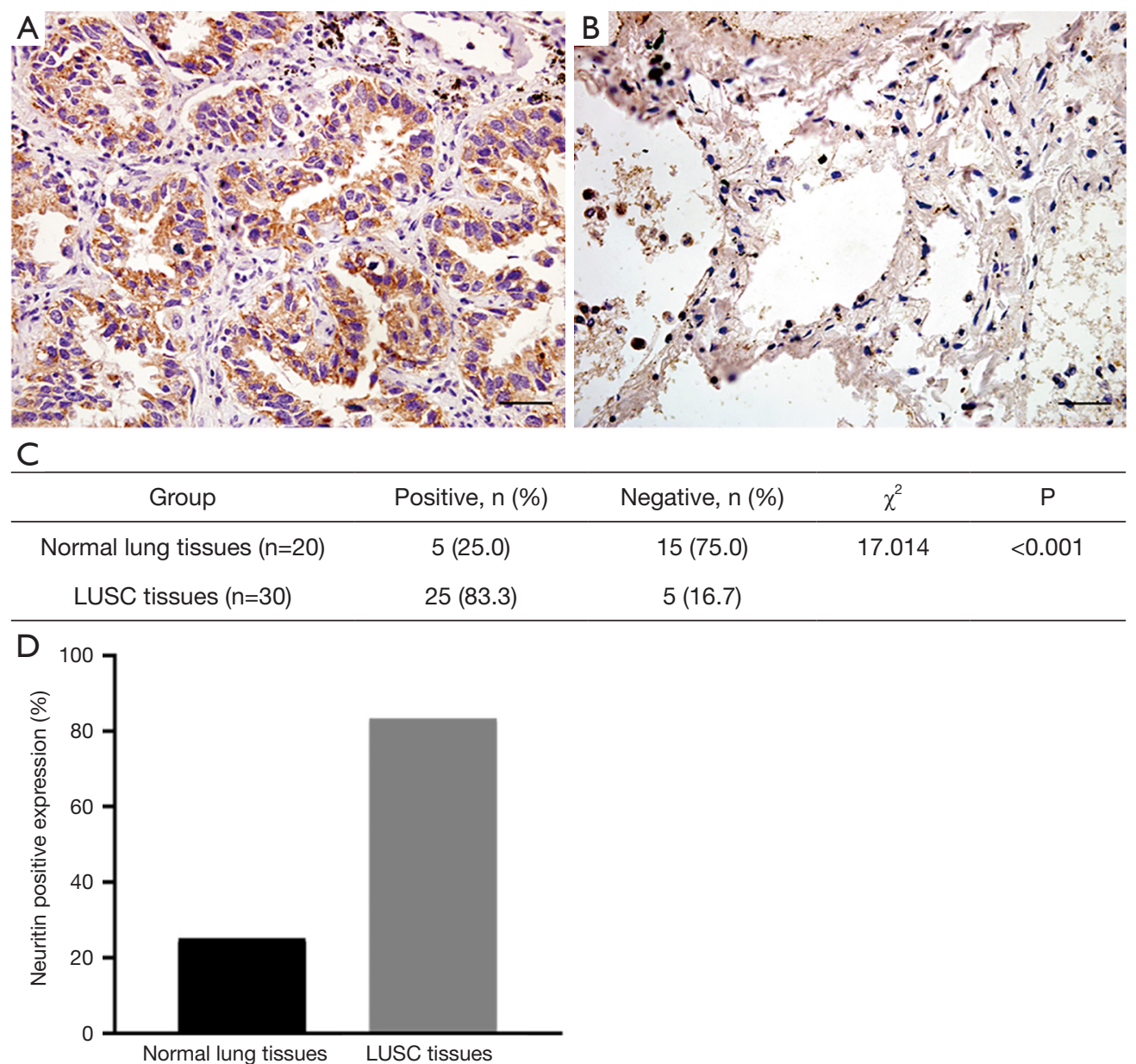

Figure 2 Neuritin protein expression levels in LUSC tissues and normal lung tissues using IHC analysis. Representative IHC images of LUSC tissues and corresponding normal lung tissues using anti-neuritin antibody (1:50 dilution). Scale bar, $100 \mu m$. (A) Positive neuritin immunoreactivity was mainly localized in the cytoplasm in LUSC tissue. (B) Neuritin expression in normal lung tissue. (C, D) Neuritinpositivity ratios in LUSC tissues and normal lung tissues $\left(\chi^{2}=17.014, \mathrm{P}<0.001\right)$.

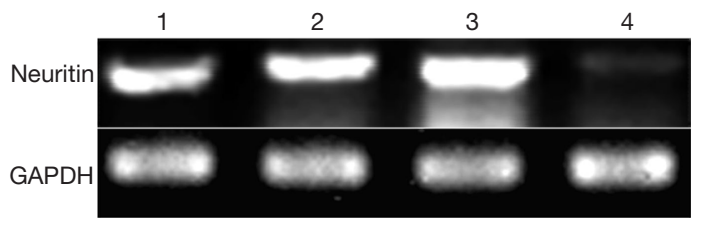

Figure 3 RT-PCR analysis of neuritin expression in human LUSC tissues and corresponding normal lung tissues. Lane 1: positive control; lanes 2 and 3: LUSC tissues; lane 4: normal lung tissues. Neuritin expression was normalized to GAPDH.

with distant metastasis.

The current results showed that neuritin expression levels were higher in LUSC than in normal lung tissue, but were negatively correlated with the degree of malignant differentiation and distant metastasis. However, these apparently contradictory findings were supported by other studies. Overexpression of neuritin significantly increased microvascular density $(16,17,20)$, and injection of NIH3T3 cells transfected with neuritin into the abdomen of nude mice resulted in the formation of abdominal tumours (25). However, neuritin also induced mesenchymal stem cells to differentiate into neuron-like cells (32), and ectopic expression of neuritin in NIH3 T3 cells resulted in changes in cell morphology and increased protuberance (25).

The present study had some limitations. We only used samples from lung squamous carcinoma, and not other types of lung cancer. In addition, our results need to be 
validated in a larger sample size in future.

Lung cancer is one of the most common causes of death worldwide (24), and the diagnosis and prognosis of LUSC, as the most common type of lung cancer, is thus of great significance. The current results suggested that neuritin may have clinical value as a novel diagnostic and prognostic marker in patients with LUSC.

\section{Acknowledgments}

We extend our sincere gratitude to Dr. Lei Yang, Dr. Jin Zhao, Dr. Xiao Lin Pan, Dr. Jiangmei Qin, and Dr. Jianxin Xie for their assistance during this study. We are also grateful to the staff of the Department of Pathology, the Affiliated Hospital of Shihezi University, for technical support. We thank International Science Editing (http:// www.internationalscienceediting.com) for editing this manuscript.

Funding: This work was supported by NSFC Grant 31060136 (J Huang) and NSFC Grant 30760063 (J Huang).

\section{Footnote}

Conflicts of Interest: The authors have completed the ICMJE uniform disclosure form (available at http://dx.doi. org/10.21037/tcr.2019.09.52). The authors have no conflicts of interest to declare.

Ethical Statement: The authors are accountable for all aspects of the work in ensuring that questions related to the accuracy or integrity of any part of the work are appropriately investigated and resolved. The study was conducted in accordance with the Declaration of Helsinki (as revised in 2013). The present study was approved by the Human Ethics Committee of the First Affiliated Hospital of Shihezi University School of Medicine (No. 2007-025-01), and written informed consent was obtained from all patients according to the committee's regulations.

Open Access Statement: This is an Open Access article distributed in accordance with the Creative Commons Attribution-NonCommercial-NoDerivs 4.0 International License (CC BY-NC-ND 4.0), which permits the noncommercial replication and distribution of the article with the strict proviso that no changes or edits are made and the original work is properly cited (including links to both the formal publication through the relevant DOI and the license). See: https://creativecommons.org/licenses/by-nc-nd/4.0/.

\section{References}

1. Nedivi E, Hevroni D, Naot D, et al. Numerous candidate plasticity-related genes revealed by differential cDNA cloning. Nature 1993;363:718-22.

2. Yao JJ, Zhao QR, Lu JM, et al. Functions and the related signaling pathways of the neurotrophic factor neuritin. Acta Pharmacol Sin 2018;39:1414-20.

3. Zhou S, Zhou J. Neuritin, a neurotrophic factor in nervous system physiology. Curr Med Chem 2014;21:1212-9.

4. Naeve GS, Ramakrishnan M, Kramer R, et al. Neuritin: a gene induced by neural activity and neurotrophins that promotes neuritogenesis. Proc Natl Acad Sci U S A 1997;94:2648-53.

5. Di Giovanni S, Faden AI, Yakovlev A, et al. Neuronal plasticity after spinal cord injury: identification of a gene cluster driving neurite outgrowth. FASEB J 2005;19:153-4.

6. Marron TU, Guerini V, Rusmini P, et al. Androgeninduced neurite outgrowth is mediated by neuritin in motor neurones. J Neurochem 2005;92:10-20.

7. Putz U, Harwell C, Nedivi E. Soluble CPG15 expressed during early development rescues cortical progenitors from apoptosis. Nat Neurosci 2005;8:322-31.

8. Karamoysoyli E, Burnand RC, Tomlinson DR, et al. Neuritin mediates nerve growth factor-induced axonal regeneration and is deficient in experimental diabetic neuropathy. Diabetes 2008;57:181-9.

9. Son H, Banasr M, Choi M, et al. Neuritin produces antidepressant actions and blocks the neuronal and behavioral deficits caused by chronic stress. Proc Natl Acad Sci U S A 2012;109:11378-83.

10. Zito A, Cartelli D, Cappelletti G, et al. Neuritin 1 promotes neuronal migration. Brain Struct Funct 2014;219:105-18.

11. Gao R, Wang L, Sun J, et al. MiR-204 promotes apoptosis in oxidative stress-induced rat Schwann cells by suppressing neuritin expression. FEBS Lett 2014;588:3225-32.

12. Choi Y, Lee K, Ryu J, et al. Neuritin attenuates cognitive function impairments in tg2576 mouse model of Alzheimer's disease. PLoS One 2014;9:e104121.

13. Zhang Y, Zhang S, Xian L, et al. Expression and purification of recombinant human neuritin from Pichia pastoris and a partial analysis of its neurobiological activity in vitro. Appl Microbiol Biotechnol 2015;99:8035-43.

14. Kojima N, Shiojiri N, Sakai Y, et al. Expression of neuritin during liver maturation and regeneration. FEBS Lett 2005;579:4562-6. 
15. Seale P, Ishibashi J, Holterman C, et al. Muscle satellite cell-specific genes identified by genetic profiling of MyoDdeficient myogenic cell. Dev Biol 2004;275:287-300.

16. Han D, Qin B, Liu G, et al. Characterization of neuritin as a novel angiogenic factor. Biochem Biophys Res Commun 2011;415:608-12.

17. Le Jan S, Le Meur N, Cazes A, et al. Characterization of the expression of the hypoxia-induced genes neuritin, TXNIP and IGFBP3 in cancer. FEBS Lett 2006;580:3395-400.

18. Han Y, Chen X, Shi F, et al. CPG15, a new factor upregulated after ischemic brain injury, contributes to neuronal network re-establishment after glutamateinduced injury. J Neurotrauma 2007;24:722-31.

19. Rickhag M, Teilum M, Wieloch T. Rapid and long-term induction of effector immediate early genes (BDNF, Neuritin and Arc) in peri-infarct cortex and dentate gyrus after ischemic injury in rat brain. Brain Res 2007;1151:203-10.

20. Zhang L, Zhao Y, Wang CG, et al. Neuritin expression and its relation with proliferation, apoptosis, and angiogenesis in human astrocytoma. Med Oncol 2011;28:907-12.

21. Pimple S, Mishra G, Shastri S. Global strategies for cervical cancer prevention. Curr Opin Obstet Gynecol 2016;28:4-10.

22. Short MW, Burgers KG, Fry VT. Esophageal Cancer. Am Fam Physician 2017;95:22-8.

23. Piulats JM, Guerra E, Gil-Martin M, et al. Molecular approaches for classifying endometrial carcinoma. Gynecol Oncol 2017;145:200-7.

Cite this article as: Liang $\mathrm{M}$, Song $\mathrm{Y}$, Zhang $\mathrm{W}, \mathrm{Xu} F$, Ba $\mathrm{P}$, Yang L, Huang J. Expression of neuritin in human lung squamous cell carcinoma. Transl Cancer Res 2019;8(6):23892395. doi: 10.21037/tcr.2019.09.52
24. Wood SL, Pernemalm M, Crosbie PA, et al. Molecular histology of lung cancer: from targets to treatments. Cancer Treat Rev 2015;41:361-75.

25. Sato H, Fukutani Y, Yamamoto Y, et al. Thalamus-derived molecules promote survival and dendritic growth of developing cortical neurons. J Neurosci 2012;32:15388-402.

26. Fujino T, Leslie JH, Eavri R, et al. CPG15 regulates synapse stability in the developing and adult brain. Genes Dev 2011;25:2674-85.

27. An K, Jung JH, Jeong AY, et al. Neuritin can normalize neural deficits of Alzheimer's disease. Cell Death Dis 2014;5:e1523.

28. Sharma TP, Liu Y, Wordinger RJ, et al. Neuritin 1 promotes retinal ganglion cell survival and axonal regeneration following optic nerve crush. Cell Death Dis 2015;6:e1661.

29. Raggo C, Ruhl R, McAllister S, et al. Novel cellular genes essential for transformation of endothelial cells by Kaposi's sarcoma-associated herpesvirus. Cancer Res 2005;65:5084-95.

30. Yuan M, Li Y, Zhong C, et al. Overexpression of neuritin in gastric cancer. Oncol Lett 2015;10:3832-6.

31. Bosserhoff AK, Schneider N, Ellmann L, et al. The neurotrophin Neuritin1 (cpg15) is involved in melanoma migration, attachment independent growth, and vascular mimicry. Oncotarget 2017;8:1117-31.

32. Zhu J, Meng P, Wang Q, et al. Effects of neuritin on the differentiation of bone marrowderived mesenchymal stem cells into neuronlike cells. Mol Med Rep 2017;16:3201-7. 